\title{
COMPETITIVENESS OF INTERNATIONAL AIRPORTS PRODUCTION INFRASTRUCTURE IN GLOBAL AIR TRANSPORTATION MARKET: COMPREHENSIVE SITUATIONAL MODEL
}

\author{
Kateryna Sydorenko ${ }^{1 *}$, Oleksandr Sydorenko ${ }^{2}$, Olena Lozhachevska ${ }^{3}$, \\ and Olha Pashchenko ${ }^{4}$ \\ ${ }^{1}$ Department of International Economic Relations and Business, Faculty of International \\ Relations, National Aviation University, Kyiv, Ukraine \\ ${ }^{2}$ Department of Airport Technologies, Aerospace Faculty, National Aviation University, \\ Kyiv, Ukraine \\ ${ }^{3}$ Department of Management, Faculty of Management, Logistics and Tourism, \\ National Transport University, Kyiv, Ukraine \\ ${ }^{4}$ Department of International Economics and World Finances, Faculty of International \\ Economics, Oles Honchar Dnipro National University, Dnipro, Ukraine \\ *Corresponding author: kateryna.sydorenko@npp.nau.edu.ua
}

Published online: 1 December 2021

To cite this article: Sydorenko, K., Sydorenko, O., Lozhachevska, O., \& Pashchenko, O. (2021). Competitiveness of international airports production infrastructure in global air transportation market: Comprehensive situational model. Asian Academy of Management Journal, 26(2), 173-195. https://doi.org/10.21315/aamj2021.26.2.8

To link to this article: https://doi.org/10.21315/aamj2021.26.2.8

\begin{abstract}
The article summarises the essence of airport infrastructure and explores the roles of production airport infrastructure in the world air transport system. It is noted that airport infrastructure is a complex dynamic subsystem of global production infrastructure of the world economy and is aimed at providing competitive air transportation services. It is substantiated that the competitive production infrastructure of international airports is a key element of the economic development of countries in the world economy. In particular, reliable airport infrastructure is one of the key factors in increasing the countries capacity for real economic growth, both in the short and long term. Generalised and systematic views of scientists have led to the conclusion that today there is no single universally accepted methodology that would comprehensively explore and evaluate the competitiveness of the airport's infrasystem, and identify its strengths and weaknesses. Therefore, this study aims to develop and substantiate the methodology for assessing
\end{abstract}

(C) Asian Academy of Management and Penerbit Universiti Sains Malaysia, 2021. This work is licensed under the terms of the Creative Commons Attribution (CC BY) (http://creativecommons. org/licenses/by/4.0/). 
the level of competitiveness of the production infrastructure of international airports in the global aviation market. The proposed methodological approach makes it possible to provide a practical assessment of the competitiveness of the airport's infrasystem, taking into account the wide range of indicators, converted through a fuzzy linguistic approach. It should be noted that the main purpose of creating and implementing an evaluation system is to facilitate the successful implementation of the competitiveness management functions of the production infrastructure of international airports in the global aviation market. The developed model may be used by international aviation organisations and governments in the process of strategic planning of the air transport development.

Keywords: airport, infrastructure, production infrastructure, competition, global competitiveness, transport sector, world market of air transportation

\section{INTRODUCTION}

Today, the importance is given to the study of airport infrastructure, its role in the global air transport system and its importance in the system of ensuring the global competitiveness. The functioning of the air transport system contributes to the international economic interaction of the countries, enhancing the processes of globalisation in the economic as well as in the social and political sphere all over the world. Due to a combination of rapid technological changes, industry consolidation, the emergence of new airline business models, the willingness of consumers to pay for safe and cost-effective services, the air transport system, as compared to other infrastructure sectors, creates opportunities for countries to integrate into global markets and for economic growth.

However, in the face of asymmetry in global economic development, the governments are forced to solve the problems of limiting airport infrastructure. There is a need for a comprehensive assessment, taking into account the situation and unique conditions that shape the determinants of the competitiveness of the production infrastructure of international airports (PIIA). This will give the ability to identify competitive advantages or disadvantages, to work out the ways to eliminate them and, in result, to strengthen the ability of airport infrastructure to contribute to the social and economic growth of countries.

The classic subdivisions of other interesting infrastructure airports and their technical schools have been thoroughly researched (Ashford \& Wright, 1992; Neufville et al., 2013). In these scientific works, the production infrastructure of the airport is mainly considered as the material base that provides the production processes of a particular airport. The airport's physical infrastructure includes 
aerodromes and runways, terminals, support facilities and equipment, and ground access infrastructure.

Lozhachevska and Palamarchuk (2009) investigated the role of transport terminals, namely airports in transport infrastructure. Scientists say that the airport is a complex dynamic system, the formation of elements of different nature, which have certain functions and properties that are missing from every other element. At the same time, the infrastructure elements of the airport that provide production activities are aerodrome, airport, and external airport complexes.

Kulyk (2010) and Avtomonov (2011) clarify the nature and classification of the infrastructure that supports the airport's production processes. They separate the airport infrastructure of aviation and non-aviation profiles, that is, that provides aviation and non-aviation activities of the airport respectively.

Sokolova (2017) in exploring the logistics concepts of airport development argues that airport infrastructure is a set of technical and technological structures, buildings, and ancillary equipment that creates all the necessary conditions for air transportation, as well as providing ground services to aviation clients.

Kharchenko (2015), and Ghryghorak and Savchenko (2017) indicate that an important condition for enhancing the competitiveness of the aviation industry is the availability of up-to-date infrastructure at the country's airports, which will be able to synchronise and coordinate the processes of transport and logistics services of appropriate quality at the optimum cost over the full supply chain. Scientists emphasise that airport infrastructure is a complex subsystem of a particular airport and, at the same time, an integral part of the transport and distribution process at the regional, national, and international levels.

Today, the international scientific community is increasingly accentuating the fact that, under the influence of internationalisation processes, airport infrastructure is not just international, but global. It is a complex dynamic subsystem of the global production infrastructure of the world economy and aims at providing competitive air transportation services. Thus, Betancor and Rendeiro (1999), Button (1996), Winston and Rus (2008), and Poltoratska (2010) investigated the features of the functioning and development of air transport infrastructure in the conditions of free trade and liberalisation of international air transport markets. They argue that in today's context, the infrastructure of individual airports cannot be considered separately, but is a composite of the transport system, complex air transportation network, goes beyond national borders and serves as a regulatory reform for governments in both developed and developing countries. 
A number of scientific papers (Neufville et al., 2013; Addie, 2014) also state that airport infrastructure is part of several airport systems at the same time, and it is not possible to separate airport systems into autonomous subsystems. Airport systems are intertwined, but in practice they are not clearly defined from the point of view of the aviation and air transport networks.

The production infrastructure of international airports influences the place that airports occupy in the global air transport market and is a necessary (but insufficient) precondition for competitiveness of the airport sector, economic region, and national economy as a whole. This assumption is supported by a number of thorough scientific studies. For example, Schamp (2002) analysed the processes of deregulation, commercialisation, and privatisation in the EU airport sector. He concluded that the indivisibility of the physical infrastructure of airports, with increased use of airports, would result in significant economies of scale. Scientist views the expansion of the physical infrastructure of international airports as a driver of economic growth.

A number of scientific papers (Kasarda, 1995; Crockatt, 2000; Addie, 2014; Wiedemann, 2014; Díez-Pisonero, 2019) investigate the relationship between airport infrastructure and their surrounding regional spaces. Scientists have proposed the concept of aeroregionalism, the essence of which is that the imperatives of globalisation and neoliberalisation enhance the regionalisation of aerodrome space, and the development of large-scale airport infrastructure affects the competitiveness of the surrounding regional space.

Graham and Marvin (2001), Graham (2003), Keast et al. (2008), Macario et al. (2011), Wang et al. (2013), Dörr et al. (2019), and Gadgin Matha et al. (2020) also noted the interdependence between the development of the country's airport infrastructure network and social and economic well-being. The conceptual approach proposed by scientists is, that airport infrastructure is regarded as an economic generator, integrating local and international markets, connecting regions globally.

Itani et al. (2014), Cortés-Villafradez and Peña-Cárdenas (2019), and Llanto and Rodolfo (2020) argue that the competitive infrastructure of international airports is one of the major determinants of the competitiveness of the air transport system at the national level and affects the overall competitiveness of the country in the global environment.

Thus, an adequate level of infrastructure is a key element in the economic development of countries in the world economy, in particular the reliable airport 
infrastructure is one of the main factors for enhancing countries' capacity for real economic growth in both the short and long term.

Therefore, this study is extremely important and relevant today, as it offers a comprehensive methodology for assessing the level of competitiveness of airport infrastructure, which allows to identify strengths and weaknesses, justify priorities and conditions for the formation of a competitive airport's infrasystem, identify trends and structural dominants of the global air transport market.

\section{LITERATURE REVIEW}

PIIA's role in ensuring the global competitiveness and its systemic nature (airport infrastructure $\rightarrow$ production infrastructure of the country's airport system $\rightarrow$ production infrastructure of the airport system of a region/group of countries $\rightarrow$ global PIIA) has been comprehensively substantiated (Sydorenko, 2014; Lozhachevska et al., 2018; Lozhachevska \& Sydorenko, 2019). Given the levels of PIIA formation, its macro- and meso-level competitiveness can be determined by considering the global competitiveness plane. This can be done in the context of the most popular indicators of country competitiveness - World Competitiveness Ranking (IMD, 2017), Global Competitiveness Index (WEF, 2020).

PIIA's competitiveness can also be seen as a major element of airports' competitiveness. And today, there is a great deal of scientific research that monitors the rating positions of airports and, of course, examines their infrastructure as a basic element of operational support. Park $(2002,2003)$ presents an analysis of the competitive status of major airports in Asia. He researched the airport infrastructure of the region, and based on a scorecard (geographical characteristics of airports, airport accessibility, environmental effects, business and operational conditions of airlines, etc.), tested the author's methodology.

Grancay (2009) proposed a concept of airport competitiveness index, which consists of four components: index of airport infrastructure, index of market potential, index of airport charges, and index of recent traffic results. Another important consideration is safety. However, the considered methodology does not take into account the financial performance of airports. Although high financial performance is vital for strategic investors in airport infrastructure.

The Moody's Global Scale airport rating methodology (Kramer et al., 2010) allows to determine the level of production airport infrastructure development 
to justify its financing decision, but does not take into account aviation safety, flight safety, and environmental and sustainable development indicators.

Andreev (2012) proposes through the prism of airports infrastructure and quality of their services to analyse the airports competitiveness in general. The author also points out that airports are a key element of the air transport system. They are part of the transport infrastructure and a strategic element in the competitiveness of the region and the country as a whole.

The methodology for measuring the level of service at the airports - Airport Service Quality, developed by Airport Council International (Nguyen, 2013) allow to rate the competitiveness of PIIA through the prism of providing an integrated air transportation service. However, this technique also makes it impossible to determine the competitiveness of PIIA taking into account the impact on different levels of the economic system.

In the research of Feltscher et al. (2017), Zurich Airport is compared with seven European competitors. Proposed methodology is based on the five main factors: spatial factors, demand factors, managerial factors, facility factors, and service factors; and each of these factors consists of so-called sub-factors. To assess the infrastructure of the airport is also partially allowed by studies of Reynaert et al. (2019) who explain the features of the future interaction of airlines and airports. The researchers proposed a practical way to identify airports based on a system of screening tests, and in particular includes an analysis of the availability of spare capacity and consistency of airport pricing behaviour with effective competition.

Moura et al. (2020) used the multivariate data analysis through a multiple regression to explore airport competitiveness from aircraft and passenger movement. Their study seeks to identify variables associated with the competitiveness of airports, based on their infrastructures, operations, and locations. The analysis includes variables such as the total area of the airport site, number of aircraft parking positions, number of airlines, quantity of aircraft movement landings and takeoffs, etc.

The three-level structure of airport competitiveness factors developed by Ren (2020) partially solves the issue of studying the competitiveness of airport production infrastructure. The author summarised the most important of them in five dimensions, including airport capacity, network quality, service quality, operation and management, and the environment. 
Therefore, it should be noted that for now there is no unified recognised methodology that would allow to comprehensively investigate and evaluate the competitiveness of the production infrastructure of international airports, to distinguish its strengths and weaknesses.

\section{METHODOLOGY}

As mathematical basis for assessing the level of competitiveness of PIIA, the fuzzy set theory is applied, the basis of which was developed by Zadeh (1975), Mamdani and Assilian (1975), and Kaufmann (1977). Fuzzy set theory makes it possible to use inaccurate and subjective expertise in the subject area in decisionmaking without formalising them in the form of traditional mathematical models, to model and optimise real processes taking into account uncertainty. The main elements used here are not numbers, but verbal (linguistic) variables concept such as big, small, good, simple, complex, hot, etc., which are fuzzy and vague. Fuzzy set theory is designed to deal with this kind of objects. The concept of fuzziness refers to classes in which there are various gradations of the degree of belonging, intermediate between the complete belonging and non-belonging of objects to this class. That is, fuzzy sets make it possible to apply a linguistic description of complex processes, to establish fuzzy connections between concepts, to predict the behaviour of the system, to form many alternative actions, to make a formal description of fuzzy decision-making rules.

Fuzzy set theory approach allows for a more complete and representative presentation of the results of the study and is conditioned by a number of reasons: the impossibility of collecting comprehensive data (trade secrets, limited information resources); plural, incomplete data is processed; the unpredictability of situational changes in external factors affecting the activities of international airports and the processes of shaping their infrastructure, as each operates in its own unique environment (Park, 2002, 2003; Leschinsky et al., 2014).

The choice of mathematical apparatus of the fuzzy set theory for estimation of the level of PIIA competitiveness is conditioned by the nature and specificity of the subject area, lack of ready software and directly applied classical models (Sydorenko, 2015).

A comprehensive situational approach to assessing the competitiveness of PIIA is appropriate in the following stages as shown in Figure 1. 
I. Selection of key indicators of competitiveness of PIIA $\left(I_{n}\right)$

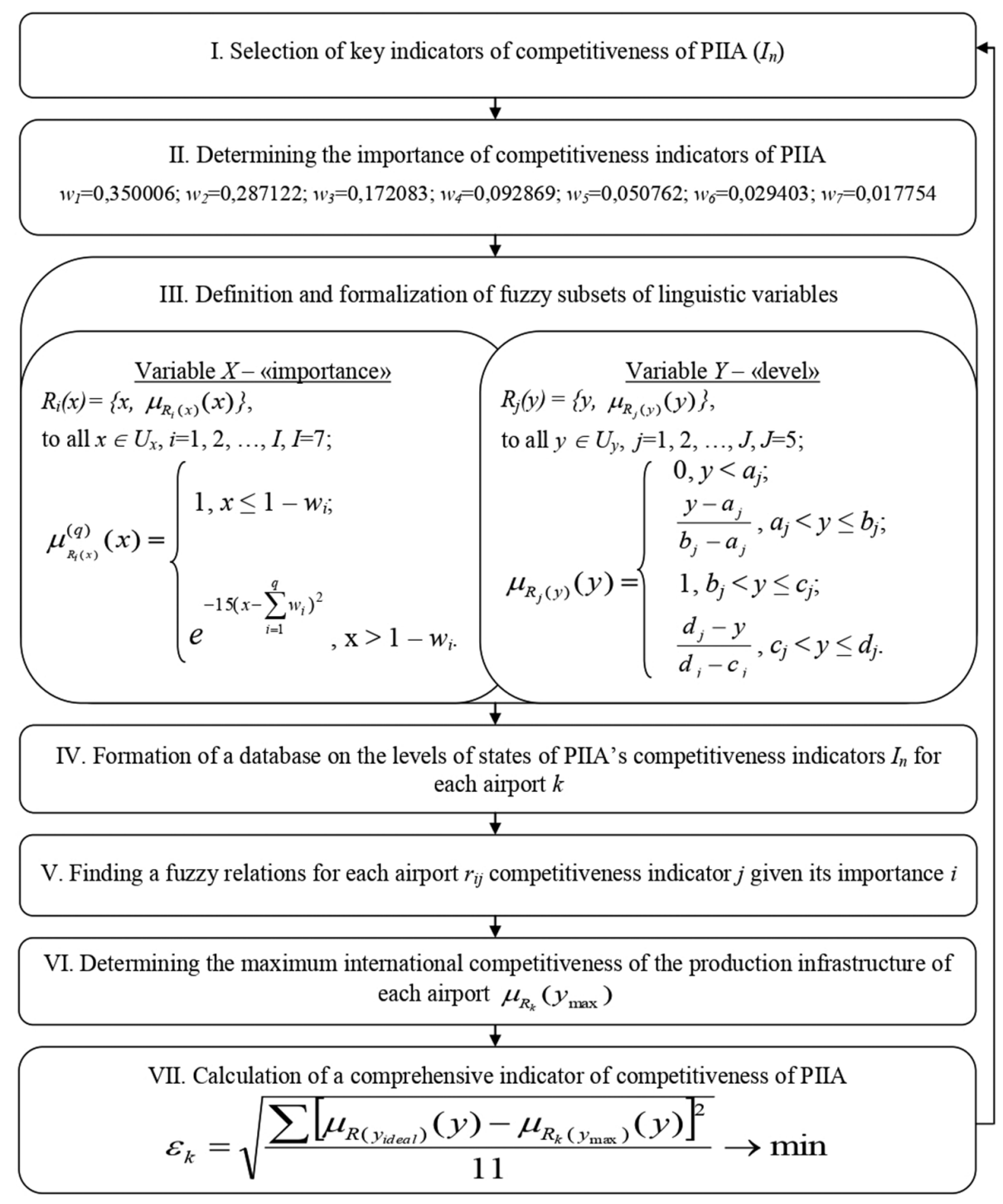

Figure 1. Stages of assessing the competitiveness of the production infrastructure of international airports

At Stage I, it is necessary to single out key indicators that determine the competitiveness of PIIA (Figure 2). Each indicator is an integrated entity and can be characterised by a set of parameters that will describe the properties of the infrastructure elements of international airports. 


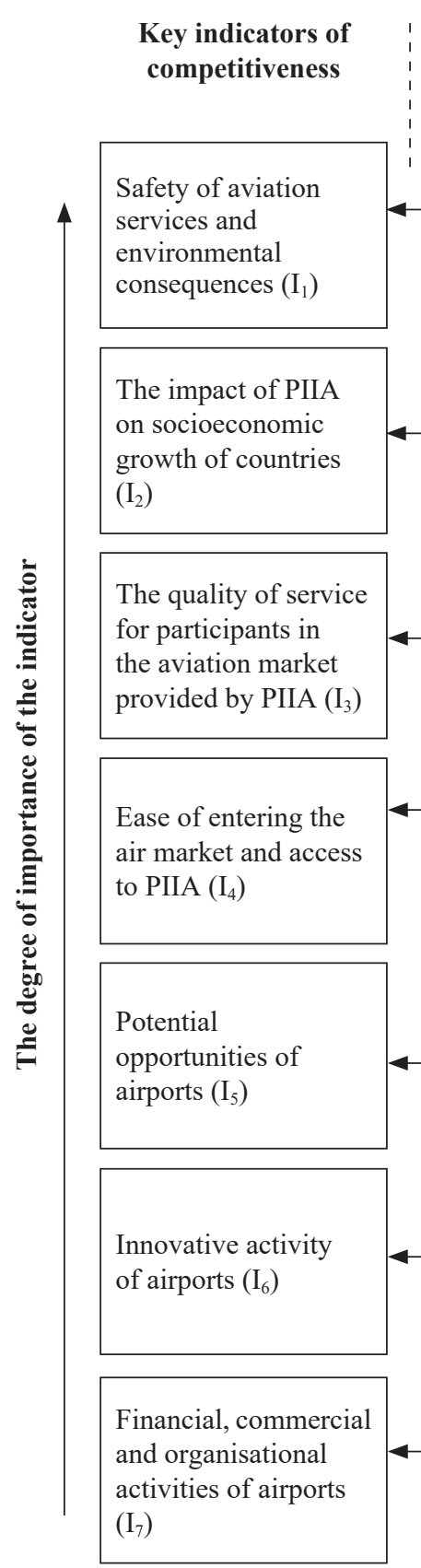

\section{Decomposition \\ competitiveness indicators}

Level of aviation safety, flight safety; ensuring environmental protection; ensuring sustainable development of airports through their infrastructure

Share of the world air transportation market; volumes of sent/received passengers/cargoes, take-offs and landings of aircraft; the number and structure of flights served; economic strength and diversity of the service area; positioning of airports; contribution to GDP; employment (direct / indirect)

Branching of the route network, frequency of flights; timeliness of sending the aircraft; diversification and price of services provided at airports; general satisfaction of passengers with comfort at airports; timeliness of delivery and storage conditions of goods, etc.

Number of airlines, handling, catering, refueling companies, cargo operators present at airports; the amount of airport fees

Geographical characteristics of airports; characteristics of the aerodrome, passenger and cargo terminals (capacity, loading intensity, degree of modernisation, etc.); operational restrictions for airport expansion, availability of development plans; characteristics of transport infrastructure around airports; the radius of the region related to the airport under investigation, the population and number of companies in this region

Adaptability of new technologies and innovative products; conducting own research, the degree of innovation; degree of application of ITT

Liquidity; profitability; income from aviation/nonaviation activities; costs; volume and structure of capital; the size and diversification of sources of investment in the development of airport infrastructure; credit rating of airports; degree of involvement in integration processes, etc.

Figure 2. The structure of the multilevel system of indicators of competitiveness of the production infrastructure of international airports 
Given the complexity and versatility of indicators that characterise the state of the production infrastructure of international airports, it is necessary to assign each of them a degree of importance (Stage II). The method of analysis of hierarchies by Thomas L. Saaty (Saaty \& Vargas, 2001; Saaty, 2008) was used to visualise the modelling process, according to which the importance of key indicators was determined by their pairwise comparison. The matrix of pairwise comparisons is diagonal and inversely symmetric. Given the vector of priorities, the results of the calculations are given in Table. 1.

Table 1

The importance of key indicators of the competitiveness of the production infrastructure of international airports

\begin{tabular}{lcc}
\hline PIIA competitiveness indicators & $i$ & Importance $\left(w_{\mathrm{i}}\right)$ \\
\hline $\begin{array}{l}\text { Safety of aviation services and environmental consequences } \\
\text { The impact of the production infrastructure of international }\end{array}$ & 1 & 0.350006 \\
$\begin{array}{l}\text { airports on the social and economic growth of countries } \\
\begin{array}{l}\text { Quality of service for aviation market participants provided by } \\
\text { the production infrastructure of international airports }\end{array}\end{array}$ & 3 & 0.287122 \\
$\begin{array}{l}\text { Ease of entering the air market and access to airport infrastructure } \\
\text { Potential opportunities of airports }\end{array}$ & 4 & 0.172083 \\
$\begin{array}{l}\text { Innovative activity of airports } \\
\text { Financial, commercial, and organisational activities of airports }\end{array}$ & 5 & 0.092869 \\
\hline
\end{tabular}

Informative indicators of reliability of determining the importance of key indicators of competitiveness of the production infrastructure of international airports were checked on the basis of the values of the indices of coherence and relative coherence. The value of relative consistency is $7.32 \%$ (not more than $10 \%$ ), which indicates the consistency of the matrix.

The proposed indicators of competitiveness of PIIA fully disclose its properties, but have indistinct limits of indicators, which leads to the use of tools for fuzzy set. The concept of fuzzy set theory allows to formalise linguistic variables, in particular, «general conditions of production», «importance», and «level of development», makes it possible to move from a set of expert assessments to a set of membership functions, combining both quantitative and qualitative indicators. Therefore at Stage III, it is necessary to introduce linguistic variables and assign membership functions to the corresponding linguistic terms. 
We introduce fuzzy linguistic variables: variable $X$ - «importance», which characterises the importance of the competitiveness indicator of PIIA; and the variable $Y$ is «level», which indicates the level of the corresponding indicator. Fuzzy subsets of the variables $X$ and $Y$ will be $R(x)$ and $R(y)$, respectively, which are defined as semantic rules for associating values with each variable. The functions of $R(x)$ to $X$ and $R(y)$ to $Y$ are given in the range of $\mathrm{U}=[0 ; 1]$. We will build a fuzzy mathematical model for assessing the competitiveness of the production infrastructure of international airports.

The fuzzy set of linguistic variable $X$ - «importance» $R_{\mathrm{i}}(x)$ is given by a pair $\left\{x, \mu_{R_{i}(x)}(x)\right\}$, for all $x \in U_{x}, i=1,2, \ldots, I, I=7$, where $\mu_{R_{i}(x)}(x)$ - membership function $x$ to $R(x)$. The membership function of these terms is calculated on the basis of a specially selected model:

$$
\mu_{R_{i}(x)}^{(q)}(x)=\left\{\begin{array}{l}
1, \quad x \leq 1-w_{i} ; \\
e^{-15\left(x-\sum_{i=1}^{q} w_{i}\right)^{2}}, \quad x>1-w_{i} .
\end{array}\right.
$$

where $w_{i}$ is the corresponding importance of the competitiveness indicator of PIIA.

Therefore, in order to set the linguistic terms and membership functions of the variable $X$ «importance», it is necessary to raise the corresponding membership function to the appropriate degree (Figure 3).

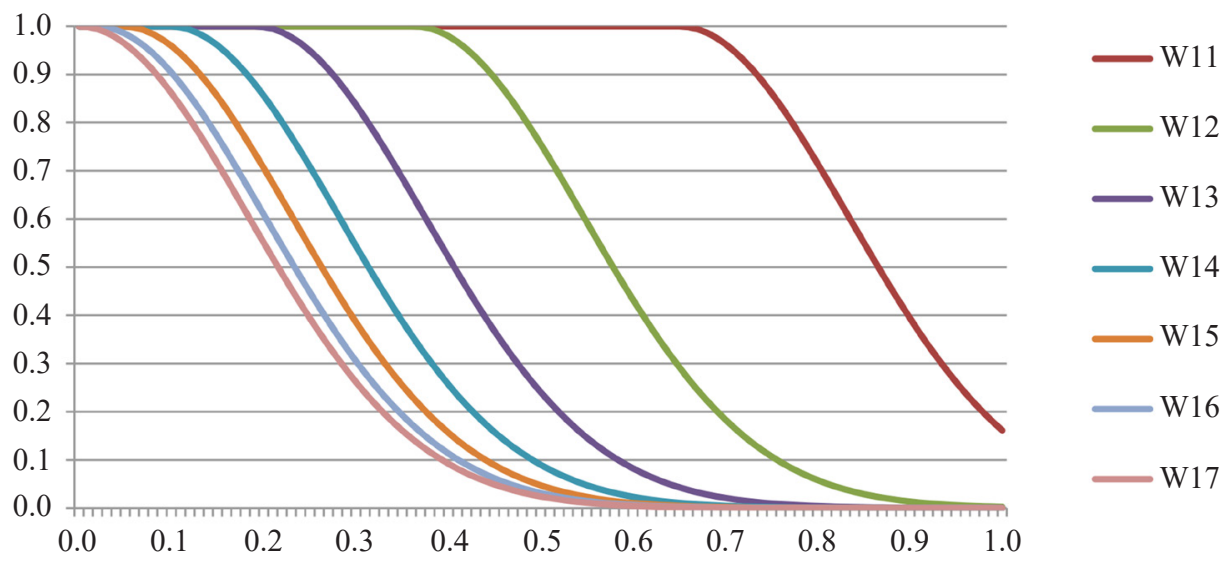

Figure 3. Graphical representation of membership functions of the linguistic variable $X$ - «importance»

Note: $W_{I i}-$ the importance of the indicator $i$ 
The degree index of exponents concentrates the membership function of a fuzzy set depending on the importance of the competitiveness indicator of PIIA.

The linguistic variable $Y-$ «level» is expressed by the fuzzy set $R_{j}(y)=\left\{y, \mu_{R_{j(y)}}(y)\right\}$, for all $y \in U_{y}, j=1,2, \ldots, J, J=5$, where $\mu_{R_{j(y)}}(y)-$ membership function y to $R(y)$. The membership function is set as follows:

$$
\mu_{R_{j}(y)}(y)=\left\{\begin{array}{l}
0, \quad y<a_{j} ; \\
\frac{y-a_{j}}{b_{j}-a_{j}}, \quad a_{j}<y \leq b_{j} ; \\
1, \quad b_{j}<y \leq c_{j} ; \\
\frac{d_{j}-y}{d_{j}-c_{j}}, \quad c_{j}<y \leq d_{j} .
\end{array}\right.
$$

where $a, b, c, d$ are the tops of trapezoidal membership functions.

It is advisable to use the Harrington scale, which provides for 5 levels of assessment in the general range from 0 to 1 , to determine the levels of the key indicators of PIIA's competitiveness.

The Harrington scale is a universal quantitative measure of the parameters of the object under study in various fields. Linguistic and quantitative characteristics of the variable $Y$ «level» taking into account the Harrington scale, adapted to the specifics of our study, are given in Table 2.

Table 2

Linguistic and quantitative characteristics of the variable $Y$ «level»

\begin{tabular}{lcccccc}
\hline & & \multicolumn{4}{c}{$\begin{array}{c}\text { The tops of trapezoidal } \\
\text { membership functions }\end{array}$} \\
\cline { 3 - 6 } Linguistic terms & $j$ & $a$ & $b$ & $c$ & $d$ \\
\hline High level of competitiveness & 5 & 0.78 & 0.88 & 1 & - \\
The level of competitiveness is above average & 4 & 0.61 & 0.69 & 0.75 & 0.82 \\
Average level of competitiveness & 3 & 0.37 & 0.49 & 0.51 & 0.63 \\
The level of competitiveness is below average & 2 & 0.18 & 0.26 & 0.32 & 0.39 \\
Low level of competitiveness & 1 & - & 0 & 0.13 & 0.22 \\
\hline
\end{tabular}


Membership functions takes into account the intervals of the Harrington scale are formalised for all terms of the linguistic variable $Y$ «level». As can be seen from Figure 4, in the zone of «absolute confidence of compliance with the level of competitiveness» the values of the membership function are taken as 1 , in the zone of «absolute confidence of non-compliance with the level of competitiveness» are marked by zero, and the zones of «uncertainty» are marked by inclined edges of the corresponding trapezoidal functions (Nedosekin, 2003, p. 46).

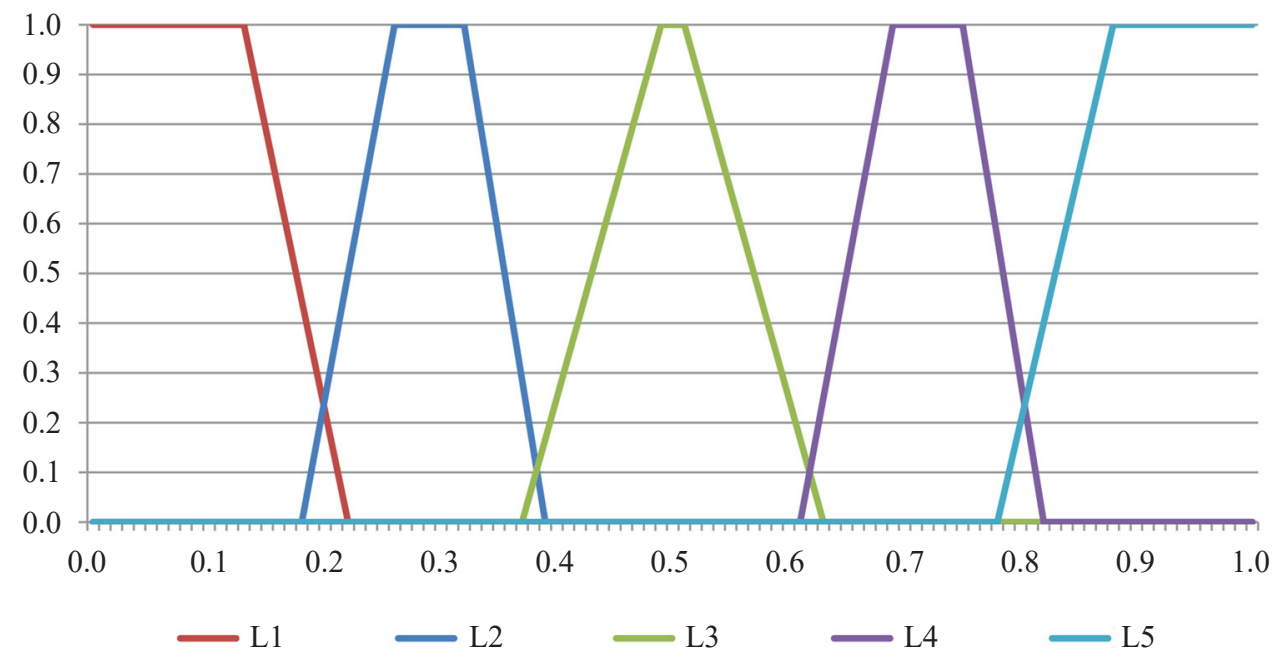

Figure 4. Graphical representation of membership functions of the linguistic variable $Y-\ll$ level»

Note: $L_{j}-j$ level of competitiveness

At Stage IV, for each international airport on the basis of indicators of competitiveness of the airport infrastructure the database on levels of states of key indicators is formed, so for each airport $k$ the level of a condition of each indicator of competitiveness of PIIA $I_{n}$ is defined.

At Stage V, for each international airport and for each indicator of the infrastructure competitiveness level $j$ taking into account its importance $i$ it is necessary to find a fuzzy relation $r_{i j}$, using in the equation the membership functions of the corresponding terms of fuzzy linguistic variables $X$ «importance» and $Y$ «level»:

$$
\mu_{r_{i j}}(x, y)=\min \left\{\min _{i}\left\{\mu_{R_{i}(x)}(x)\right\}, \mu_{R_{j}(v)}(y)\right\}
$$


At Stage VI, we determine the maximum competitiveness of the production infrastructure of each international airport $\mu_{R_{k}}\left(y_{\max }\right)$, which is described by the rule of the composition of the output:

$$
\mu_{R_{k}}\left(y_{\max }\right)=\max \left\{\min \left\{\min _{i}\left\{\mu_{R_{i}(x)}(x)\right\}, \mu_{R_{j}(v)}(y)\right\}\right\}
$$

Thus, the truncated membership functions are considered and combined with the operation «max» - for each international airport, a combined output of a fuzzy subset is constructed as a point maximum for all fuzzy subsets.

At Stage VII, conversion of a fuzzy set of conclusions to a certain number. As a criterion indicator of the competitiveness of the production infrastructure of international airports, it is proposed to use the relative Euclidean distance, where the shortest distance will be an indicator of the highest level of competitiveness:

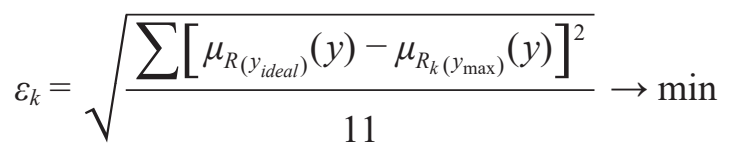

where $\mu_{R_{\left(y_{\text {ideal }}\right)}}(y)$ is the function of belonging to the ideally highest level of international competitiveness of the airport's production infrastructure, $\mu_{R_{k}\left(y_{\max }\right)}(y)$ is the function of belonging to the maximum level of international competitiveness of the production infrastructure of the studied airport. Thus, the final step of the proposed methodology is to determine the competitive position of the production infrastructure of individual airports.

The developed complex and situational model for assessing the level of competitiveness of PIIA can be applied by international aviation organisations and governments in the process of strategic development of the production infrastructure of international airports. Also, international aviation institutions are offered the creation of a single information space and the maintenance of relevant statistics with comprehensive data, ongoing analytical activities on each of the indicators of the competitiveness of airport infrastructure. 


\section{RESULTS}

To test the model, international airports from different regions of the world economy were selected (Table 3), as well as the leading airport in Ukraine Boryspil International Airport.

Table 3

List of international airports selected for testing the integrated situational model of competitiveness assessment of PIIA

\begin{tabular}{rll}
\hline No. & $\begin{array}{l}\text { Airport (International Air Transport } \\
\text { Association airport code) }\end{array}$ & Airport location \\
\hline 1. & Boryspil International Airport (KBP) & Boryspil, Ukraine, Europe \\
2. & Cape Town International Airport (CPT) & $\begin{array}{l}\text { Cape Town, South Africa, Africa } \\
\text { Dubai, UAE, Middle East }\end{array}$ \\
3. & Dubai International Airport (DXB) & Atlanta, USA, North America \\
4. & Hartsfield-Jackson Atlanta International & Airport (ATL) \\
5. & Hong Kong International Airport (HKG) & $\begin{array}{l}\text { Cheklapkok, Hong Kong, Asia-Pacific } \\
\text { Region }\end{array}$ \\
6. & London Heathrow Airport (LHR) & London, Great Britain, Europe \\
7. & Mexico City International Airport (MEX) & Mexico City, Mexico, Latin America \\
8. & Paris-Charles de Gaulle Airport (CDG) & Paris, France, Europe \\
9. & Singapore Changi Airport (SIN) & Changi, Singapore, Asia-Pacific Region \\
10. & Tokyo Haneda International Airport (HND) & Tokyo, Japan, Asia-Pacific Region \\
\hline
\end{tabular}

The characteristics of key indicators of the competitiveness of airport production infrastructure are based on data by Centre of Aviation (CAPA, 2018), Airports Council International (ACI, 2020), Air Transport Action Group (ATAG, 2020), International Air Transport Association (IATA, 2020), and International Civil Aviation Organization (ICAO, 2020).

There is no doubt that Asian airports have a highly developed infrastructure and are centres of trade and business. Hong Kong International Airport is one of the most striking examples of the dynamic growth of airports in the field of both sent and received passengers (74.517 million people) and loaded/unloaded cargo (5120.8 thousand tons). It is the largest cargo hub in the world. The branching of the route network includes 180 directions, of which 45 are within the AsiaPacific Region. The strategy of the airport envisages the development of airport infrastructure without environmental barriers, aims to be a "green airport." A $\$ 12.4$ billion direct impact in GDP. 
Tokyo Haneda International Airport is the third largest in the Asia-Pacific Region (87.5 million people). The users of infrastructure services are 40 passenger and 6 cargo airlines. The branching of the route network has 245 directions. Innovations are introduced in infrastructure facilities that reduce the time of passenger service, cargo handling, aircraft maintenance. A $\$ 8.3$ billion direct impact in GDP.

Singapore Changi Airport is the largest in Singapore and also one of the major hubs in Asia. The total number of transported passengers in 2018 was 65.63 million people, of which $60 \%$ are in international traffic. The total amount of transported cargo is 2195 thousand tons, 391 thousand take-offs and landings of aircraft. The main goal of the airport is to accelerate the socioeconomic development of Singapore. A $\$ 4.5$ billion direct impact in GDP. Asia's airports owe much of their success to public aviation policies aimed at striking a balance between public investment in airport infrastructure development and the admission of private investors and operators to airport management.

In the mature European market, large airports are characterised by a slight increase in passenger and freight traffic due to the lack of capacity reserves. Although many airports have excess capacity to meet growing demand, the capacity of runways and terminals of some of them has reached its limit. The result is the largest airport and air navigation fees at London Heathrow Airport and Paris-Charles de Gaulle Airport.

London Heathrow Airport is one of the largest in the world in terms of the number of passengers carried ( 80.126 million people, of which $37 \%$ are transfers). The first airport in London in terms of the amount of cargo transported - 1771.342 thousand tons. The total number of received and sent aircraft is 478 thousand take-offs and landings. The branching of the route network is 170 destinations, 83 airlines. A $\$ 5.6$ billion direct impact in GDP. The airport is highly profitable. The owner and operator of the airport is Heathrow Airport Holdings (formerly British airport authority).

Paris-Charles de Gaulle Airport is the busiest airport in continental Europe. The total number of served passengers in 2018 is 72.23 million people, transported goods are 2156 thousand tons. The airport infrastructure provided 488 thousand take-offs and landings of aircraft. There are 152 airlines at the airport, which provide 329 connections. A \$12.5 billion direct impact in GDP. Management and financing of infrastructure projects is provided by the global corporation Aéroports de Paris. 
Boryspil International Airport is the leading airport in Ukraine. Due to the modernisation of the infrastructure and successful implementation of the hub strategy, it annually increases the volume of activity. The airport is located at the intersection of many air routes (from Europe to Asia, America and back) and is the only airport in Ukraine capable of accepting all types of aircraft without restrictions and providing transcontinental flights. Boryspil International Airport provides $64 \%$ of passenger air traffic in Ukraine. Its infrastructure can serve 12.6 million passengers (2018), of which $80 \%$ is in international traffic; total amount of processed cargo is 40.9 thousand tonnes, of which $99 \%$ is international; the annual number of take-offs and landings of aircraft is 96.94 thousand. The airport infrastructure provides a standard set of aviation and non-aviation services for participants in the transportation process at a high price. The users of the airport infrastructure are 45 foreign and 9 Ukrainian passenger airlines, and 8 cargo airlines. These direct activities contributed approximately $\$ 120$ million to GDP. The credit rating of the airport is B2.

In the United States, Hartsfield-Jackson Atlanta International Airport provides the largest total passenger traffic in the world (107.394 million people). It ranks second in the number of take-offs and landings of aircraft (896 thousand). The airport operates flights to 214 destinations, including 84 international flights to 54 countries. The airport has 24 passenger and 19 cargo airlines. Over the past 15 years, the airport has been implementing a $\$ 10$ billion infrastructure expansion program. A $\$ 10.3$ billion direct impact in GDP. Airport credit rating is A1.

Mexico City International Airport adheres to high standards of environmental protection. The total number of passengers served is 47.7 million, the number of processed cargoes is 581.67 thousand tons, serviced take-offs and landings of aircraft is 458.59 thousand. The branching of the route network of the airport is more than 100 destinations in different parts of the world. The airport services are used by 30 passenger airlines, 17 cargo airlines. The airport is owned by Grupo Aeroportuario de la Ciudad de México and is operated by Aeropuertos y Servicios Auxiliares, a public-private corporation that manages 22 other airports in Mexico.

Cape Town International Airport is the second busiest airport in South Africa, the third busiest in Africa. The total capacity of the terminals is 14.5 million passes for a year. The airport has 27 airlines serving more than 100 destinations. A number of environmental measures are being implemented, in particular the re-profiling of the runway in order to reduce the impact on the environment. It directly contributes $\$ 449.8$ million in GDP. The airport is managed by a state-owned company that manages the system of African airports within the entire airport network - Airports Company South Africa SOC Ltd. Airport credit rating is A2. 
The airports of the Middle East are marked by dynamic rates of activity. Dubai International Airport is one of the most attractive places for business and leisure in the region, as it has become a base of connection for long-haul international flights from East and West, North and South. The airport is the world's largest transit hub for freight. The total number of passengers is 89.15 million people per year, transported cargo of 2641.38 thousand tons, 408 thousand take-offs and landings of aircraft. A $\$ 4.5$ billion direct impact in GDP. The airport infrastructure provides a high level of safety and compliance with environmental standards.

In the next step, we used the method of expert assessments using the adapted Harrington scale to analyse key indicators of airport infrastructure competitiveness. Next, we calculated the functions of belonging to the maximum competitiveness of the production infrastructure for each of the analysed airports.

After the final mathematical calculations in Table 4, the resulting values of competitive positions of the production infrastructure of the studied airports are presented.

Table 4

Competitive positions of the production infrastructure of international airports

\begin{tabular}{lcc}
\hline Name of the airport (code by IATA) & $\varepsilon_{k}$ & Rating position \\
\hline Hong Kong International Airport (HKG) & 0.0131 & 1 \\
Hartsfield-Jackson Atlanta International Airport (ATL) & 0.0616 & 2 \\
Singapore Changi Airport (SIN) & 0.0829 & 3 \\
Paris-Charles de Gaulle Airport (CDG) & 0.3501 & 4 \\
Tokyo Haneda International Airport (HND) & 0.3561 & 5 \\
Dubai International Airport (DXB) & 0.3563 & 6 \\
London Heathrow Airport (LHR) & 0.3744 & 7 \\
Mexico City International Airport (MEX) & 0.3914 & 8 \\
Cape Town International Airport (CPT) & 0.4627 & 9 \\
Boryspil International Airport (KBP) & 0.5502 & 10 \\
\hline
\end{tabular}

Because according to the method of calculating the relative Euclidean distance, the shorter distance indicates higher competitiveness, so the first place corresponds to the lowest value of the indicator $\varepsilon_{k}$, Hong Kong International 
Airport (0.0131), Hartsfield-Jackson Atlanta International Airport (0.0616), and Singapore Changi Airport (0.0829) have the highest rating positions, which is ensured by a high level of almost all competitiveness indicators of PIIA.

The average position of European airports is due to the high demand for infrastructure services and the inability to meet them in full, which is the reason for frequent delays of aircraft flights. The situation is complicated by the problem of expanding the territory of airports for the construction of new infrastructure facilities.

In turn, the Boryspil International Airport ranks last in the ranking (0.5502), which indicates the low competitiveness of its production infrastructure compared to the analysed airports, despite the fact that it is the leading airport in Ukraine.

\section{CONCLUSION}

The importance of the study is that the proposed methodological approach makes it possible to provide a practical assessment of the competitiveness of the production infrastructure of international airports, taking into account a wide range of assessment indicators, convertible due to a fuzzy linguistic approach. It should be noted that the main purpose of creating and implementing an assessment system is to promote the successful implementation of the functions of managing the competitiveness of the production infrastructure of international airports in the global air transport market.

However, our study has several limitations. First, there are data limitations. The creation of a single information space by international aviation institutions will contribute to a detailed analysis and a deeper understanding of the impact of each indicator on the airport infrastructure competitiveness. Second, the study does not fully take into account the impact of global aviation alliances on the formation of airport infrastructure. Today, there are examples of successful financing and infrastructure development by such strategic airport alliances as the Galaxi International Cargo Alliance, the Pantares Alliance between Fraport and Schiphol Group, Schiphol Group and Aéroports de Paris airports, and more. Airport alliances provide rapid exchange of know-how and operational infrastructure management, affecting its competitiveness. This sets the direction for further research. 
Therefore, future research will focus on the study of mechanisms for implementing the functions of managing the competitiveness of the production infrastructure of international airports in the global air transport market, including the adding airports to strategic aviation alliances and taking into account the regional context.

\section{ACKNOWLEDGEMENTS}

The study was funded by the National Aviation University (no. 14-2020/15.01.01 "Strategic priorities of economic development of Ukraine in the conditions of digitalization of the world economy").

\section{REFERENCES}

Addie, J. (2014). Flying high (in the competitive sky): Conceptualizing the role of airports in global city-regions through «aero-regionalism». Geoforum, 55(1), 87-99. https://doi.org/10.1016/j.geoforum.2014.05.006

Air Transport Action Group (ATAG). (2020). Aviation/benefits beyond borders. Retrieved 3 April 2020 from http://aviationbenefits.org.

Airports Council International (ACI). (2020). Airport statistics and data centre. Retrieved 3 April 2020 from http://www.aci.aero/Data-Centre.

Andreev, A. V. (2012). Metodicheskie osnovy formirovaniya pokazateley otsenki konkurentosposobnosti aeroporta. Nauchnyy Vestnik MGTU GA, 181(7), 12-18. [In Russian].

Ashford, N., \& Wright P. (1992). Airport Engineering. West Sussex: Wiley. https://doi .org/10.1002/9780470172896

Avtomonov, O. A. (2011). Upravlinnja investuvannjam rozvytku aeroportiv. $\mathrm{PhD}$ dissertation, National aviation university. [In Ukrainian].

Betancor, O., \& Rendeiro, R. (1999). Regulating privatized infrastructures and airport services. Washington: World Bank. https://doi.org/10.1596/1813-9450-2180

Button, K. (1996). Ownership, investment and pricing of transport and communications infrastructure. In D.F. Batten, \& C. Karlsson (Eds.), Infrastructure and the complexity of economic development. Berlin: Springer. https://doi.org/10.1007/ 978-3-642-80266-9 9

Centre of Aviation (CAPA). (2018). Aviation needs not just more infrastructure, but better infrastructure. Retrieved 3 April 2020 from https://centreforaviation .com/news/iata-aviation-needs-not-just-more-infrastructure-but-better -infrastructure-764546.

Cortés-Villafradez, R. A., \& Peña-Cárdenas, D. (2019). Analysis of transport infrastructure development and competitiveness in the member countries of the Pacific Alliance (2007-2016). Revista Finanzas y Política Económica, 11(2), 277-297. https://doi.org/10.14718/RFYPE.2019.11.2.2209 
Crockatt, M. (2000). Airport infrastructure and regional development: A case for resurrecting the growth pole concept. Winnipeg: University of Manitoba.

Díez-Pisonero, R. (2019). Airports and cities in the context of globalisation: A multidimensional symbiosis in Adolfo Suárez-Madrid Barajas Airport. The Geographical Journal, 185(4), 485-497. https://doi.org/10.1111/geoj.12299

Dörr, L., Dorn, F., Gaebler, S., \& Potrafke, N. (2019). How new airport infrastructure promotes tourism: Evidence from a synthetic control approach in German regions. Working paper no. 18. Munich: University of Munich.

Feltscher, B., Wittmer, A., \& Linden, E. (2017, July). A model for measuring airport competitiveness: The case of Zurich Airport. Paper presented at the Annual World Conference 2017 Air Transport Research Society (ATRS), Antwerp, Belgium.

Gadgin Matha, S., Goldstei, P., \& Lu, J. (2020). Air transportation and regional economic development: A case study for the new airport in South Albania. Harvard: Harvard University.

Ghryghorak, M. Ju., \& Savchenko, L. V. (2017). Loghistychni koncepciji rozvytku aeroportiv. K.: Loghos. [In Ukranian].

Graham, A. (2003). Managing airports: An international perspective. New York: Routledge. https://doi.org/10.1002/jtr.407

Graham, S., \& Marvin, S. (2001). Splintering urbanism: Networked infrastructures, technological mobilities and the urban condition. London: Routledge. https://doi.org/10.4324/9780203452202

Grancay, M. (2009). Evaluating competitiveness of airports: Airport competitiveness index. Bratislava: MPRA.

IMD. (2017). What is the IMD world competitiveness ranking? Retrieved 3 April 2020 from https://www.imd.org/uupload/imd.website/wcc/factor_breakdown.pdf.

International Air Transport Association (IATA). (2020). Economic performance of the airline industry. Retrieved 3 April 2020 from http://www.iata.org/publications/ economics/Pages/index.aspx?menu=Outlook\&cat=Industry\%20Economic $\% 20$ Performance.

International Civil Aviation Organization (ICAO). (2020). Annual reports of the Council. Retrieved 3 April 2020 from https://www.icao.int/about-icao/Pages/annual -reports.aspx.

Itani, N., O’Connell, J., \& Mason, K. (2014). A macro-environment approach to civil aviation strategic planning. Transport Policy, 33, 125-135. https://doi.org/ 10.1016/j.tranpol.2014.02.024

Kasarda, J. D. (1995). Transportation infrastructure for competitive success. Transportation Quarterly, 50(1), 35-50.

Kaufmann, A. (1977). Introduction a la theorie des sous-ensembles flous/elements theoriques de base. Paris: Masson.

Keast, R., Baker, D., \& Brown, K. (2008, November). Balancing Infrastructure for the airport metropolis. Paper presented at the International Conference on Infrastructure Systems: Building Networks for a Brighter Future, Rotterdam, the Netherlands. https://doi.org/10.1109/INFRA.2008.5439666 
Kharchenko, M. V. (2015). Efektyvni metody upravlinnja infrastrukturoju aeroportu pry zastosuvanni zovnishnikh profesijnykh loghistychnykh kadriv. Formuvannja rynkovykh vidnosyn v Ukrajini, 4, 163-168. [In Ukranian].

Kramer, L., Fowler, P., Hazel, R., Ureksoy, M., \& Harig, G. (2010). Airport cooperative research program. Washington, DC: The National Academies Press.

Kulyk, V. A. (2010). Investycijni resursy innovacijnykh proektiv modernizaciji aeroportiv. Problemy pidvyshhennja efektyvnosti infrastruktury, 27. Retrieved 3 April 2020 from http://jrnl.nau.edu.ua/index.php/PPEI/article/view/169. [In Ukranian].

Leschinsky, O., Bugajko, D., \& Sokolova, N. (2014). Theoretical aspects of modeling fuzzy controller for management system of electric energy consumption by airports. Eastern-European Journal of Enterprise Technologies, 6[2(72)], 54-60. https://doi.org/10.15587/1729-4061.2014.30843

Llanto, G., \& Rodolfo, M. C. (2020). The state of competition in the air transport industry: A scoping exercise. Quezon City: Philippine Competition Commission.

Lozhachevska, O., \& Sydorenko, K. (2019). Formuvannja konkurentospromozhnosti vyrobnychoji infrastruktury mizhnarodnykh aeroportiv. K.: FOP Maslakov.

Lozhachevska, O., Sydorenko, K., \& Sidenko, S. (2018). Global laws of the development of the global aviation market. The Journal of International Economic Policy, 2(29), 55-74. https://doi.org/10.33111/iep.2018.29.03

Lozhachevska, O. M., \& Palamarchuk, Ju. A. (2009). Formuvannja strateghiji ekonomichnogho rozvytku pasazhyrsjkogho terminalu aeroportu. K.: Kondor. [In Ukranian].

Macario, R., Peneda, M., \& Reis, V. (2011). Critical factors for the development of airport cities. Transportation Research Board, 18, 1-15. https://doi.org/10.3141/ 2214-01

Mamdani, E., \& Assilian, S. (1975). An experiment in linguistic synthesis with a fuzzy logic controller. Man-Machine Studies, 7, 1-13. https://doi.org/10.1016/S0020 -7373(75)80002-2

Moura, F.H.S., Caetano, M., \& Severino, M.R. (2020). Airport competitiveness analysis from aircraft and passenger movement. Journal of Transportation and Logistics, 5(2), 143-157. https://doi.org/10.26650/JTL.2020.0015

Nedosekin, A. (2003). Fuzzy financial management. Moscow: AFA Library.

Neufville, R., Odoni, A., Belobaba, P., \& Reynolds, T. (2013). Airport systems: Planning, design, and management. New York: McGraw-Hill.

Nguyen, S. (2013). Airport service quality. Programme rules and guidelines. Geneva: DKMA.

Park, Y. (2002). Evaluating the competitive status of Incheon international airport among major Asian airports. Goyang-city: Korea Transport Institute.

Park, Y. (2003). An analysis for the competitive strength of Asian major airports. Journal of Air Transport Management, 9, 353-360. https://doi.org/10.1016/ S0969-6997(03)00041-3

Poltoratska, O. T. (2010). Global institutional cooperation international aviation organizations with airports in Ukraine. PhD dissertation, National Aviation University. 
Reynaert, T., von Hinten, N., \& Veronese B. (2019). The future airline-airport relationship and the question of market power. Journal of Airport Management, 13(4), $322-334$.

Ren, J. (2020). Two-stage interval best-worst method for weighting: Prioritization of influential factors of airport competitiveness. In: Advanced operations management for complex systems analysis (Springer Briefs in Applied Sciences and Technology). Springer, Cham. https://doi.org/10.1007/978-3-030 $-45418-02$

Saaty, T. L. (2008). Decision making with the analytic hierarchy process. International Journal of Services Sciences, 1(1), 83-98. https://doi.org/10.1504/IJSSCI.2008 .017590

Saaty, T. L., \& Vargas, L. G. (2001). Models, methods, concepts and applications of the analytic hierarchy process. Norwell: Kluwer Academic Publishers. https://doi.org/10.1007/978-1-4614-3597-6

Schamp, E. W. (2002). From a transport node to a global player: The changing character of the Frankfurt airport. In D. Felsenstein, E.W. Schamp, \& A. Shachar (Eds.), Emerging nodes in the global economy: Frankfurt and Tel Aviv compared. London: Kluwer. https://doi.org/10.1007/978-94-017-1408-2_7

Sokolova, O. Je. (2017). Rozvytok loghistychnoji infrastruktury aeroportu. In M. Ju. Ghryghorak, \& L. V. Savchenko (Eds.), Loghistychni koncepciji rozvytku aeroportiv. K.: Loghos. [In Ukranian].

Sydorenko, K. (2014). Mechanisms of development the competitiveness of the productive infrastructure of international airports in conditions of intensification of the global air transport market. European Applied Sciences, 4, 129-130.

Sydorenko, K. (2015). Evaluation of competitiveness of production infrastructure of the world market of air transportation. Austrian Journal of Humanities and Social Sciences, 9-10, 133-137. https://doi.org/10.20534/AJH-15-9.10-133-137

Wang, Y., Chou, C., \& Yeo, G. (2013). Criteria for evaluating aerotropolis service quality. The Asian Journal of Shipping and Logistics, 29, 395-414. https://doi .org/10.1016/j.ajs1.2013.12.006

Wiedemann, M. (2014). The role of infrastructure for economic development in an airport metropolis' region. Lismore: Southern Cross University.

Winston, C., \& Rus, G. (2008) Aviation infrastructure performance: A study in comparative political economy. Washington, DC: Brookings Institution Press.

World Economic Forum (WEF). (2020) Global competitiveness report. Retrieved 3 April 2020 from https://www.weforum.org/reports/global-competitiveness -report-2019.

Zadeh, L. (1975). The concept of a linguistic variable and its application to approximate reasoning I. Information Sciences, 8, 199-251. https://doi.org/10.1016/0020 $-0255(75) 90036-5$ 